\author{
K.B. Umbrashko, N.E. Bulankina
}

\title{
«THE TIME OF TROUBLES»: HISTORIOGRAPHICAL, SOURCE AND EDUCATIONAL DOMINANTS
}

\begin{abstract}
The article presents the analysis of the Concept of a new educational and methodological complex on Russian history in the framework of one of the "difficult" issues in Russian history, i.e. "attempts to limit the power of the head of the state during the period of Turmoil and in the time of Palace coups, possible causes and consequences for the failure of these attempts". It is shown that the XVII and XVIII centuries cannot be connected with each other only by "attempts to limit" the power of the Supreme ruler, since this is not completely justified with historical literature and source studies. The article concludes with a tentative statement of mythologies for identifying the features of the Time of Troubles in Russia at the beginning of the XVII century, many of which are misleading and controversial, even erroneous assumptions.

Keywords: historiography, source studies, «Time of Troubles», historical mythology. Historical and Cultural standard (ICS), «difficult» questions of history.
\end{abstract}

\section{Introduction}

In the year of 2013, the Ministry of Education and Science of the Russian Federation and the Russian historical society developed the Concept of a new educational and methodological complex on Russia's history (the Concept) [1-4]. The Concept develops the Historical and Cultural Standard (ICS) and the List of «difficult questions» on Russia's history. A lot of time has passed since the adoption of the Concept, but the List of «difficult questions» still causes a lot of controversy in the pedagogical, both historical and humanitarian environment [5-9].

Recent scholarship has formulated one of these «difficult questions» of Russian history in an innovative way in the ICS, as is the following, "Attempts to limit the power of the head of state during the period of Turmoil and in the era of Palace coups, possible reasons for the failure of these attempts». In the ICS this «difficult question» is divided chronologically into two parts, i.e. «Turmoil» and «Palace coups». The first part of «Time of Troubles» of the early XVII century is included into section II of the ICS «Russia in XVI-XVII centuries from the Grand Duke to the Kingdom». The second part, «Palace coups» of the XVIII century is included into section III of the ICS «Russia at the end of the XVII-XVIII centuries: from the Kingdom to the Empire».

In recent scholarship the events of the XVII and XVIII centuries are treated differently, sometimes quite the other way round. The fact is that the XVII century Russian history is not equal to the history of the XVIII century. The authors of modern history textbooks for high school decided to associate these two periods with the «attempts to limit» the power of the Supreme ruler by some agreements with him. It seems that this is not entirely justified in historical literature. Therefore, our article is devoted only to the first part of this «difficult question», i.e. the «Time of Troubles» at the beginning of the XVII century. At the same time, we did not limit ourselves to the historiographical and source aspects of this important and «difficult» historical problem. In brief, the purpose of this article is to identify by presentation its methodological potential fully.

\section{Methodology and programme of the research}

Thus, there presented the materials of the ICS for thorough discussion and investigation, where in the explanatory note of ICS there is a statement, according to which «...the struggle for power between the boyar families against the background of worsening socio-economic situation (famine, 1601-1603), as well as the intervention of frontier countries / neighbors, primarily, Commonwealth, into the internal affairs of Russia, contributed to the country's accession for the first time in its history, the civil war, in terms of contemporaries received the title "the Time of Troubles", which lasted during fifteen years (1604-1618)» [3. P. 24].

By the same token, the general idea of this statement does not contradict the conclusions of modern historiography. The only question is the chronology of the time of troubles. According to the N. M. Karamzin «History of the Russian state», the starting point of the troubles was considered to be the suppression of the Rurik dynasty in 1598, and its end, on the one hand, and the beginning of the Romanov dynasty in 1613, on the other hand, are found in traditional scholarship.

With some reservations, it still haunts the national historical tradition throughout the XIX century (S.M. Solovyov, V.O. Klyuchevskii, etc.) and the XX century (S.F. Platonov, R.G. Skrynnikov, etc.). The dating of the ICS (1604-1618) causes confusion both among educators and scientists, assessing the impact on Russian society, on historical literature, source criticism and studies of this period of time. It should be noted that this dating does not occur further on in the ICS text. Most likely, while working as a history teacher, one ought to adhere to the traditional chronology.

Other accents of the ICS explanatory note have more journalistic than scientific essence. There is a contrast between the negative and positive characteristics of the events. Negative characteristics assess a negative impact on recent scholarship because of the phrases like «a series of impostors», «foreign invaders», «occupation of cities, including the capital», «social actions», «separatism of the 
countryside», «the threat of loss of national independence». Positive phrases sound as "consolidation of society», the success of the people's Militias, «council of all the Earth», the feat of Prince D. Pozharsky and the citizen K. Minin, preserving the independence of the Moscow state. These misleading descriptions of the Time are much more inaccurate byproducts of historical journalism than of authentic scholarship.

The effect of the conclusion of the ICS is the explanatory note about the high price that Russia paid for the turmoil of the Troubles, namely, the economic crisis, material, territorial, and human losses, these examples do not sound dramatically. Contrary to the drama of Russia's nightmarish Time of Troubles, the payment for the «frivolity» of the people of the early twentieth century was not as high as it could have been. Especially, after the election of the Zemstvo Council in 1613, since the time of the new Russian Tsar, Mikhail Fedorovich Romanov (1613-1645), there was a rapid and calm situation for the society and the restoration of state institutions. However, these state institutions had a completely different essence, the class representation took a firm course to formalize absolutism in Russia.

Unfortunately, the purpose and the mission of absolutism is not immediately apparent. The formation of a new configuration of the state leads to the strengthening of the Central government in a paradoxical way through the rapid activities of the Zemstvo councils in the first half of the XVII century, when the most important issues of both national and foreign policy were solved in a «democratic» way. But this was a «tactical retreat» of absolutism and ultimately contributed to the formation of an absolute monarchy at a new stage in Russian history of the XVIII century. That is why, in our opinion, it is not correct to compare historical processes of the XVII and XVIII centuries: a class-representative monarchy is not equal to an absolute monarchy. As is the case, it needs further consideration and investigation.

\section{Discussion of the results}

A closer look at the issues show that the above events are presented fully in the ICS work program where one can find slightly different accents, e.g. «Turmoil in Russia. The dynasty crisis. Zemsky Sobor in 1598, and the election of Tsar Boris Godunov. Boris Godunov's policy and the boyar clans. Opal of the Romanov family. The famine of 1601-1603 and the aggravation of the socio-economic crisis». "The time of troubles at the beginning of the XVII century, its causes and consequences. Impostors and pretenders. The identity of the pretender Dmitry I ("false tsar") and his policies. The revolt (1606), and the murder of an impostor». "Tsar Vasilii Shuiskii. The "Bolotnikov rebellion". The development of an internal crisis into the civil war. The pretender Dmitry II. Invasion of the territory of Russia by Polish-Lithuanian regiments / detachments. The Tushino camp of the pretender, near Moscow. Defence of the Trinity-Sergiev monastery. Vyborg Treaty between Russia and Sweden. The March of M.V. SkopinShuiskii's and Ya.-P. Delagardi's troops, and the collapse of the Tushinskii camp. Entry into the war against Russia of the Polish-Lithuanian Commonwealth. The Defence of Smolensk». "The overthrow of Vasilii Shuiskii, and the transfer of power to the "Council of Seven". Agreement on the election of the Polish Prince Vladislav to the throne, and the entry of the Polish-Lithuanian army in Moscow. The rise of the national liberation movement. Patriarch Hermogenes. The Moscow uprising (1611), and the burning of the city by the occupants. The first and second militias. Capture of Novgorod by Swedish troops. "Council of the Whole Earth". Liberation of Moscow (1612)». «Zemsky Sobor (1613), and its role in strengthening the State. The establishment of the Romanov dynasty (starting with Mikhail Fedorovich). The fight against the Don cossacks' uprisings against the Central government. Stolbovsky peace with Sweden: loss of access to the Baltic Sea. Continuation of the war with the Polish-Lithuanian Commonwealth. Prince Vladislav's March to Moscow. Conclusion of the Deulin armistice with the Polish-Lithuanian Commonwealth. Results and consequences of the Time of Troubles» [3. P. 26].

In traditional scholarship, speaking of «attempts to limit the power of the head of state during the Turmoil», apparently means «the agreement on the recognition of the king's son, Vladislav as the new Russian Tsar». Here is a paragraph from this «Treaty...» (1610) for to be discussed. «<...> And on the measure the sovereign Prince Vladislav Zhigimontovich was established in the Russian state, and about that episode, we boyars, gave the Hetman a letter on articles, and on those articles the Hetman gave us, the boyars, a record, and approved it with his hand and seal, and on that record the Hetman and all the colonels kissed the cross for the great sovereign, Zhigimont the Tzar; and we, in the reigning city of Moscow, are to crown the state with a Royal crown on the former rank. And being the king's son, Vladislavovich Zhigimontovich, on the Russian state of the Church of God, in all the cities and villages, honor and protect from ruin, and the Holy Icons of God and miraculous relics of worship, churches and other faiths of prayer churches in the Moscow state do not put anywhere; and what the Hetman did say, so that in Moscow at least one Church could be for people of Poland and Lithuania, who, the king's son, with the Patriarch and with all the spiritual rank and boyars and with all the people of the Duma, speak; and our Christian Orthodox faiths of the Greek law do not destroy or dishonor anything, and do not introduce any faiths; so that our Holy Orthodox faith of the Greek law has its integrity and beauty. And what is given to the Churches of God and monasteries of serfdoms or lands, are not taken away. The boyars, nobles, and the rest of the people who have all sorts of state affairs are still there; and the Polish and Lithuanian people in Moscow do not have any affairs in the cities and voivodeships and clerks are not there. Former customs and ranks have not changed, and the Moscow princes and the boyar families, foreigners do not lower. Salary, money and lands, something had to be let alone still. The court alone is still the custom, and the law of the Russian state will pochotal what popolnit for strengthening ships, and the Emperor on povolite with the Duma of the boyars and of the whole world. And who is to blame, that the fault of his kazniti, condemning in advance with the boyars and Duma men; 
a wife, children, brethren, that matter did not do, those do not kazniti, and estates they have not ottimati/taken away; and not find guilty and condemned by the court of all the boyars, no kazniti. The sovereign's revenues from cities, from counties, also from taverns and from the tamog veleti (the customs) are still collected by the sovereign, not pogovori with the boyars. And those cities from the war were desolate, and those cities and counties sent to the sovereign to describe and dosirati, a lot of things were lost, and the income of veleti imati on the inventory and on the watch; and on the emptied estates dati benefits, after talking to the boyars. Merchants can trade freely as before. And about the thief that is called Tsarevich, Dmitry Ivanovich, to the Hetman trade with us, boyars, as if that thief izymati or kill; and as the thief withdraw or will be killed, and to the Hetman and all his troops, from Moscow to depart. But only a thief Moscow Popocat what is the theft or enforced cinity, and the Hetman against that thief of state and fight with him. And in everything to the king's son, Vladislav Zhigimontovich, delati on our petition, and under the contract with the great sovereign, Zhigimont, and to this authorized record. And about Epiphany, so that the Sovereign, King's son, Vladislav Zhigimontovich, will be granted baptisms in our Orthodox Christian faith and be in our Orthodox Christian Greek faith; and about other false articles and about all sorts of affairs, as if between the sovereigns and their States, the agreement about everything, and the completion was made. And for approval to this record, we put our seals, the boyars, and the deacons attributed their hands» [10]. Thus, it's important to bear in mind the fact of that the King's son Vladislav never became a Russian Tsar. Perhaps because of the geopolitical claims of his father, the Polish King, Sigismund the Third.

In recent scholarship the study of the Troubles of the early XVII century covers the significant content potential of forming new approaches, techniques, and methods for key and problematic periods of Russian history. The turmoil in Russia at the beginning of the XVII century is undoubtedly one of the most interesting periods in the history of our Fatherland. The main source studies and historical literature of this time are the selection of texts where various aspects of the Troubles are under discussion. E.g. the relevance of the topic itself is of great importance; historiographic concepts of the Troubles, including mythologems; the specific historical event outline of the era; the content of sources are available for both teachers and researchers.

By the same token, the relevance of the above problem is confirmed by a modern researcher, D. A. Gutnov, who is sure of the fact that «It is not the first time when our Fatherland passes the stage of its development, which is traditionally called the Turmoil among the people. As is the case, the natural question arises: what is this phenomenon of our historical reality, under what conditions it occurs, what are its integral components, what are their main development trends, what are the consequences for the country, and what can be the ways and methods that allow, if not to pass this stage at all, then to weaken its negative consequences» [11. P. 4]. The historiographical aspects of the topic are closely related to its relevance «for all the times»: "Among such periods of timelessness throughout the historical path of our country, the time that most clearly absorbed and reflected all the characteristics of the phenomenon of Russian Turmoil, are considered to be the events of the beginning of the XVII century, in the Moscow state. Most of the Russian scholars of the past considered the events of those distant days very closely and tried to make conclusions from them» [Ibid. P. 4].

According to R. G. Skrynnikov, the greatest Russian historian, «the historiography of the Time of Troubles» is very extensive. In traditional scholarship the XVIII century historians were influenced by the Russian chronicle tradition. V.N. Tatishchev saw the reasons for the «Turmoil» in the serfdom legislation of Boris Godunov. In the XIX century, the historiographer N. M. Karamzin, considered the Turmoil in Russia to be the result of foreign interference in the internal affairs of the Moscow state. Russian state, in his opinion, was the result of disharmony between the traditional ideas and principles of Russian statehood and the moral foundations of the Russian population that were shaken during the reign of Ivan IV. S. M. Solovyov linked the Turmoil with the dynasty crisis. N. I. Kostomarov saw a large role of the free cossacks in the events of the Troubles [12. P. 3].

\section{Conclusion}

As is the case, in terms of historiography, most of the above trends are significant. We think that it is a must to add some historiographical ideas as perspective ones:

- Turmoil as a political struggle for power between the old family aristocracy and the new palace nobility; as a socio-economic struggle for land and workers' hands (V.O. Klyuchevskii; S.F. Platonov). Turmoil is «a painful, full of stupid perplexity mood of society, which was created by the open outrages of oprichnina and dark Godunov intrigues» [13. P. 46]. V.O. Klyuchevskii clarified this statement: «...in the course of the Turmoil, two supported conditions are particularly clear: this is imposture / "false tsars" and social disorder / misery / chaos» [Ibid. P. 48].

- Turmoil / smuta - social / peasant revolution (M.N. Pokrovskii).

- Smuta - uprising under the leadership of I.I. Bolotnikov (I.V. Stalin).

- Smuta - Polish-Swedish intervention (Soviet historiographical tradition / traditional scholarship).

- Turmoil - myth, legend, anecdote (in the sense of an entertaining story).

As an example of myth-making, we can suggest for consideration a well-known change of the name of M.I. Glinka's opera, dedicated to the history of Ivan Susanin's feat: «Life for the Tsar»- «For the hammer and sickle» - «Ivan Susanin». This example is a byproduct associated with the cruelty of Ivan IV, the quietness and the sanctity of Fyodor Ioannovich, the bad blood of Boris Godunov, the interruption of the Rurik dynasty, the activity of "false tsars", predictors Dmitrievs, the machinations of the Poles, and popular speeches. Myth-making was intertwined with naturalism and precise chronology. Russian historian N.I. Kostomarov wrote: «In different places of the Moscow Region, terrible storms uprooted trees, turned over bell towers in cities, and tore off roofs. Here no fish were caught in the water; there no birds were seen 
at all; there a woman gave birth to a freak; there a pet produced such a monster that it was impossible to tell what it was. They began to see the two Suns and two months in the sky. To complete all the horrors, a comet appeared: it was so large that on the second Sunday after Trinity day, 1604 , it was seen at noon [14. P. 51].

In recent foreign scholarship great interest for the Time of Troubles in Russia at the beginning of the XVII century is noticed [15-18]. According to Chester S.L. Dunning, the Troubles ought to be a prime candidate for scrutinity by students of political violence in Russian history because of a tentative assessment of the impact both on Russian society and political culture of high level terror. This author is certain of the fact that the final stage of the Troubles witnessed a lot of acts of extreme cruelty, the usage of terror, a devastated country whose population longed for relief and stability.

Research on regional history is also essential for recent scholarship of the subject [19]. Based on historiography, the main historical ideas can be formulated this way:

- State origin of Russian history.

- Unusual, inverted events for contemporaries, when «no one is equal to oneself», and the order is followed by disorder. According to Russian historian S. M. Solovyov, «...dwelt a terrible habit not to respect life, honor and property of the others; the brokenness of the rights of the weak before the strong, in the absence of enlightenment, the fear of a public trial, fear of the court of other nations, in a society which had not yet come, the person is put in a distressing situation, making him a victim of accidents, men were forced to comply with these accidents, but this habit to comply with contingencies, of course, could not contribute to the development of civil respect for their dignity, ability to choose civil devices/means for solution of purposes» [20. P. 377-378].

- Turmoil is a moment of testing the strength of state power, and at the same time, it is a factor of stabilization, strengthening of the state principle. N. M. Karamzin wrote about the false Dmitry I: «Ridiculous courage and unbelievable happiness of reaching the goal - some charm motivates the hearts and minds of men contrary to common sense - making (there is no equal example in History) a fugitive Monk, the Cossack-robber, and the servants of Lithuanian pan in three years into the King of a great Power, the Impostor seemed cool, calm, not surprised, among the glamour and grandeur, that surrounded him in this time of confusion, shame and shamelessness» [21. P. 119-120].

As is the case, the ICS does not consider most of the postulates of political events of the XVII and XVIII centuries. This leads to a deformation of historical logic. By the same token, the ICS does not take into account the results of both national and foreign historiography. It is clear that students do not have to tell about the birth of freaks and monsters. Clearly, that history teaches nothing, but only punishes for unlearned lessons [22. P. 347].

How prophetic these words of the great historian, V.O. Klyuchevskii are!

\section{REFERENCES}

1. Vestnik obrazovaniya. (2014). 13.

2. Gefter.ru. (2013) Kontseptsiya novogo uchebno-metodicheskogo kompleksa po otechestvennoy istorii [The concept of a new educational and methodological complex on national history]. [Online] Available from: http://gefter.ru/archive/10162 (Accessed: 20th January 2020).

3. Rushistory. (n.d.) Kontseptsiya novogo uchebno-metodicheskogo kompleksa po otechestvennoy istorii [The concept of a new educational and methodological complex on national history]. [Online] Available from: http://rushistory.org/proekty/kontseptsiya-novogo-uchebno-metodicheskogokompleksa-po-otechestvennoj-istorii.html (Accessed: 20th January 2020).

4. Kommersant.ru. (2013) Kontseptsiya novogo uchebno-metodicheskogo kompleksa po otechestvennoy istorii [The concept of a new educational and methodological complex on national history]. [Online] Available from: http://www.kommersant.ru/docs/2013/standart.pdf (Accessed: 20th January 2020).

5. Vyazemsky, E.E. \& Strelova, O.Yu. (2015) Pedagogicheskie podkhody $k$ realizatsii kontseptsii edinogo uchebnika po istorii [Pedagogical approaches to the implementation of the concept of a unified history textbook]. Moscow: Prosveshchenie.

6. Umbrashko, K.B. (2016) The concept of a new educational and methodological complex on Russian history: difficult questions of history or historiography. Sibirskiy uchitel' - Siberian Teacher. 5(108). pp. 16-21. (In Russian).

7. Umbrashko, K.B. \& Fedina, N.G. (2017) "Trudnye voprosy" otechestvennoy istorii $i$ varianty ikh resheniy ["Difficult questions" of national history and options for their solutions]. Novosibirsk: NIPKiPRO

8. Umbrashko, K.B., Oleynikov, I.V., Solovieva, E.A. \& Fedina, N.G. (2018) Reshenie “trudnykh voprosov” istoriko-kul'turnogo standarta kak mekhanizm modernizatsii soderzhaniya predmeta $v$ ramkakh realizatsii Kontseptsii novogo UMK po otechestvennoy istorii [Solving the "difficult issues" of the historical and cultural standard as a mechanism for modernizing the content of the subject within the framework of implementing the Concept of a new Educational and Mothodoligical Complex on National History]. Novosibirsk: NIPKiPRO.

9. Oleynikov, I.V. \& Fedina, N.G. (2018) "Trudnye voprosy" istorii Rossii pervoy poloviny XX veka ["Difficult questions" of the Russian history of the first half of the 20th century]. Novosibirsk: NIPKiPRO.

10. Anon. (n.d.) Dogovor o priznanii korolevicha Vladislava russkim tsarem [Agreement on the recognition of the King's son, Vladislav, as the Russian Tsar]. [Online] Available from: http://refdb.ru/look/1876311-p7.html (Accessed: 20th January 2020).

11. Gutnov, D.A. (1994) Lyudi i sobytiya Smutnogo vremeni [People and events of the Time of Troubles]. Moscow: GITIS.

12. Skrynnikov, R.G. (1988) Rossiya v nachale XVII v. Smuta [Russia in the early 17th century. Turmoil]. Moscow: Mysl'.

13. Klyuchevsky, V.O. (1989) Sochineniya. V 9 t. [Works. In 9 vols]. Vol. 3. Moscow: Mysl'.

14. Kostomarov, N.I. (1994) Smutnoe vremya Moskovskogo gosudarstva a nachale XVII stoletiya [The Time of Troubles of the Moscow State in the Early 17th Century]. Moscow: Charli.

15. Dunning, Ch.S.L., Martin, R., Rowland, D.B. (2008) Rude \& Barbarous Kingdom Revisited: Essays in Russian History and Culture in Honor of R.O. Crummey. Bloomington: Slavica.

16. Dunning, Ch.S.L. (2010) Russia's First Civil War: The Time of Troubles and the Founding of the Romanov Dynasty. University Park: Pennsylvania State University Press.

17. Mjør, K.J. (2018) Smuta: cyclical visions of history in contemporary Russian thought and the question of hegemony. Studies in East European Thought. 70(1). pp. 19-40. DOI: 10.1007/s11212-018-9298-0

18. Petersson, B. (2013) The eternal great power meets the recurring Time of Troubles: Twin political myths in contemporary Russian politics. European Studies. 30. pp. 301-326. DOI: 10.1163/9789401208895_013 
19. Bulankina, N.E. \& Umbrashko, K.B. (2018) Regional history in the formation and development of the personality of students. Sibirskiy uchitel' Siberian Teacher. 1(116). pp. 69-74.

20. Soloviev, S.M. (1989) Sochineniya v 18 kn. [Works in 18 vols]. Moscow: Mysl'.

21. Karamzin, N.M. (1989) Istoriya gosudarstva Rossiyskogo [History of Russian Statehood]. Vol. 9. Moscow: Kniga.

22. Klyuchevsky, V.O. (2007) Aforizmy i mysli ob istorii [Aphorisms and thoughts about history]. Moscow: Eksmo.

Умбрашко Константин Борисович, Новосибирский институт повышения квалификации и переподготовки работников образования (Новосибирск, Росссийская Федерация). E-mail: hitstorian09@ mail.ru

Буланкина Надежда Ефимовна, доктор философских наук, Новосибирский институт повышения квалификации и переподготовки работников образования (Новосибирск, Российская Федерация). E-mail: NEBN@ yandex.ru

СМУТНОЕ ВРЕМЯ: ИСТОРИОГРАФИЧЕСКИЕ, ИСТОЧНИКОВЕДЧЕСКИЕ И ОБРАЗОВАТЕЛЬНЫЕ ДОМИНАНТЫ Ключевые слова: историография; источниковедение; Смутное время; историческая мифология; Историко-культурный стандарт (ИКС); «трудные» вопросы истории.

Целью данного исследования является историографический и источниковедческий анализ Концепции нового учебнометодического комплекса по отечественной истории с точки зрения одного из «трудных» вопросов истории России: «Попытки ограничения власти главы государства в период Смуты и в эпоху дворцовых переворотов, возможные причины неудач этих попыток». Источниковая база данного исследования носит в основном историографический характер. Это тексты Н.М. Карамзина («История государства Российского»), С.М. Соловьева («История России с древнейших времен»), В.О. Ключевского («Курс русской истории»), Н.И. Костомарова («Смутное время Московского государства в начале XVII столетия») и др. Кроме того, подробно анализируются учебные и методические источники (Историко-культурный стандарт - ИКС). В ходе проведенного исследования были сделаны следующие выводы. Современная историография по-разному, порой совершенно противоположным образом трактует события XVII и XVIII вв. Авторы современных учебников по истории для средней школы решили связать эти две эпохи «попытками ограничения» власти верховного правителя некими договоренностями с ним. Представляется, что «историографически» это не вполне оправданно. Курс на абсолютизм проявился не сразу. Формирование новой конфигурации государства привело к укреплению центральной власти через деятельность Земских соборов в первой половине XVII в., когда самые важные вопросы как внутренней, так и внешней политики решались «демократическим» образом. Это было «тактическим отступлением» абсолютизма и в конечном счете способствовало оформлению абсолютной монархии на новом этапе истории России в XVIII в. Поэтому авторы исследования ограничились историографическим анализом лишь первой части этого «трудного вопроса» - «Смуты» начала XVII в. При этом, помимо историографических и источниковедческих аспектов этой «трудной» исторической проблемы, выявлен ее методический потенциал. Охарактеризованы некоторые историографические тенденции: Смута как политическая борьба за власть между старой родовой аристократией и новой дворцовой знатью; как социально-экономическая борьба за землю и рабочие руки; Смута - восстание народных масс; Смута - польско-шведская интервенция; Смута - миф, легенда, анекдот. Отмечено, что и зарубежная историография проявляет большой интерес к событиям и урокам Смуты в России. Историки обращают внимание на необычность, «перевернутость» событий для современников, когда место порядка занимает беспорядок. Смута стала испытанием прочности государственной власти и, парадоксальным образом, фактором стабилизации, укрепления государственного начала. Историографические оценки показывают, что одинаковая трактовка политических событий XVII и XVIII вв. в ИКС приводит к деформации исторической логики, ИКС не учитывает тенденций в изучении Смуты отечественной и зарубежной историографии. Вне поля зрения ИКС остались и исторические мифологемы.

\section{ЛИТЕРАТУРА}

1. Вестник образования. 2014. № 13.

2. Концепция нового учебно-методического комплекса по отечественной истории. URL: http://gefter.ru/archive/10162 (дата обращения: 20.01.2020)

3. Концепция нового учебно-методического комплекса по отечественной истории. URL: http://rushistory.org/proekty/kontseptsiya-novogouchebno-metodicheskogo-kompleksa-po-otechestvennoj-istorii.html (дата обращения: 20.01.2020).

4. Концепция нового учебно-методического комплекса по отечественной истории. URL: http://www.kommersant.ru/docs/2013/standart.pdf (дата обращения: 20.01.2020).

5. Вяземский Е.Е., Стрелова О.Ю. Педагогические подходы к реализации концепции единого учебника по истории : пособие для учителей общеобразовательных организаций. М. : Просвещение, 2015.78 с.

6. Умбрашко К.Б. Концепция нового учебно-методического комплекса по отечественной истории: «трудные вопросы» истории или «трудные вопросы» историографии? // Сибирский учитель : науч.-метод. журнал. 2016. № 5 (108). С. 16-21.

7. Умбрашко К.Б., Федина Н.Г. «Трудные вопросы» отечественной истории и варианты их решений : учеб.-метод. пособие. Новосибирск : Изд-во НИПКиПРО, 2017. 108 с.

8. Умбрашко К.Б., Олейников И.В., Соловьева Е.А., Федина Н.Г. Решение «трудных вопросов» Историко-культурного стандарта как механизм модернизации содержания предмета в рамках реализации Концепции нового УМК по отечественной истории : учеб. пособие. Новосибирск : Изд-во НИПКиПРО, 2018. $156 \mathrm{c}$.

9. Олейников И.В., Федина Н.Г. «Трудные вопросы» истории России первой половины ХХ века: учебно-методическое пособие / под ред. А.В. Запорожченко. Новосибирск : Изд-во НИПКиПРО, 2018. 184 с.

10. Договор о признании королевича Владислава русским царем. URL: http://refdb.ru/look/1876311-p7.html (дата обращения: 20.01.2020).

11. Гутнов Д.А. Люди и события Смутного времени. М. : ГИТИС, 1994. 80 с.

12. Скрынников Р.Г. Россия в начале XVII в. «Смута». М. : Мысль, 1988. 283 с.

13. Ключевский В.О. Сочинения : в 9 т. / под ред. В.Л. Янина; послесл. и коммент. В.А. Александрова, В. Г. Зиминой. М. : Мысль, 1989. Т. ІІІ: Курс русской истории, ч. $3.414 \mathrm{c.}$

14. Костомаров Н.И. Смутное время Московского государства в начале XVII столетия. Исторические монографии и исследования. М. : Чарли, 1994. $800 \mathrm{c}$.

15. Dunning Ch.S.L., Martin R., Rowland D.B. Rude \& Barbarous Kingdom Revisited : Essays in Russian History and Culture in Honor of R.O. Crummey. Bloomington : Slavica, 2008. 513 p.

16. Dunning Ch.S.L. Russia's First Civil War: The Time of Troubles and the Founding of the Romanov Dynasty. University Park, Pennsylvania : Pennsylvania State University Press, 2010.637 p. 
17. Mjør K.J. Smuta: cyclical visions of history in contemporary Russian thought and the question of hegemony // Studies in East European Thought. 2018. Vol. 70, is. 1. P. 19-40.

18. Petersson B. The eternal great power meets the recurring Time of Troubles: Twin political myths in contemporary Russian politics // European Studies. 2013. Vol. 30. P. 301-326.

19. Буланкина Н.Е., Умбрашко К.Б. Regional history in the formation and development of the personality of students [Региональная история в становлении и развитии личности обучающихся] // Сибирский учитель : науч.-метод. журнал. 2018. № 1 (116). С. 69-74.

20. Соловьев С.М. Сочинения : в 18 кн. / отв. ред.: И.Д. Ковальченко, С.С. Дмитриев. М. : Мысль, 1989. Кн. IV: История России с древнейших времен, т. 7-8. $752 \mathrm{c}$.

21. Карамзин Н.М. История государства Российского : репринт. воспроизведение изд. 1842-1844 гг. : в 3 кн. с приложением. М. : Книга, 1989. Кн. III: Тома IX, X, XI, XII. Разд. паг.

22. Ключевский В.О. Афоризмы и мысли об истории. М. : Эксмо, 2007. 479 с. 